\title{
Realia funkcjonowania grup poszukiwawczo-ratowniczych w Polsce
}

\author{
Patrycja Mencel \\ ORCID: 0000-0001-9560-4410 \\ Katedra Kryminalistyki \\ Wydział Prawa, Administracji i Ekonomii Uniwersytetu Wrocławskiego
}

\section{Wstęp}

W wypadku zaistnienia zdarzenia polegającego na zaginięciu osoby $^{1}$ tylko adekwatna reakcja podmiotów zaangażowanych w zwalczanie zjawiska może przynieść oczekiwane efekty, czyli doprowadzić do odnalezienia osoby zaginionej.

Kluczowy w wypadku zaginięcia osoby wydaje się być zatem zakres czynności podjętych przez służby poszukiwawcze. Podmiotem wiodącym jest oczywiście policja, jednak od kilku lat obserwuje się powstawanie grup poszukiwawczo-ratowniczych zarówno w strukturach państwowej i ochotniczej straży pożarnej, jak i w postaci stowarzyszeń cywilnych, grup działających przy PCK czy ochotniczego pogotowia ratunkowego (tatrzańskiego, górskiego lub wodnego). Współpraca państwowych służb

1 Zgodnie z $§ 2$ Zarządzenia nr 48 Komendanta Głównego Policji z dnia 28 czerwca 2018 roku w sprawie prowadzenia przez Policję poszukiwania osoby zaginionej oraz postępowania w przypadku ujawnienia osoby o nieustalonej tożsamości lub znalezienia nieznanych zwłok oraz szczątków ludzkich (Dziennik Urzędowy Komendy Głównej Policji 2018, poz. 77) zaginięcie osoby to zaistnienie zdarzenia uniemożliwiającego ustalenie miejsca pobytu osoby fizycznej, które wymaga podjęcia określonych czynności w celu jej odnalezienia. 
poszukiwawczych z innymi podmiotami specjalizującymi się w akcjach poszukiwawczych zwiększa szanse na uratowanie życia zaginionemu, a ponadto wiele cywilnych stowarzyszeń posiada specjalistyczny sprzęt, którym często nie dysponują służby państwowe.

\section{Skala zjawiska}

Przedstawiona analiza danych statystycznych dotyczy okresu od 2004 do 2018 roku. W wyniku przystąpienia Polski do Unii Europejskiej zaszło wiele zmian w zakresie regulacji prawnych dotyczących m.in. swobody przepływu osób, a w konsekwencji wzrosła liczba emigrantów. Fakt ten może być jednym z wielu elementów wpływających na rozmiary zjawiska.

Tabela 1. Liczba zgłoszonych osób zaginionych w ciągu roku

\begin{tabular}{|c|c|}
\hline Rok & Liczba osób \\
\hline 2018 & 17212 \\
\hline 2017 & 19563 \\
\hline 2016 & 19445 \\
\hline 2015 & 20458 \\
\hline 2014 & 20845 \\
\hline 2013 & 19617 \\
\hline 2012 & 17969 \\
\hline 2011 & 15616 \\
\hline 2010 & 14393 \\
\hline 2009 & 15076 \\
\hline 2008 & 15881 \\
\hline 2007 & 15671 \\
\hline 2006 & 15345 \\
\hline 2005 & 14210 \\
\hline 2004 & 15160 \\
\hline
\end{tabular}

Źródło: Dane statystyczne policji, http://statystyka.policja.pl/st/wybrane-statystyki zaginieni /50885,Zaginieni.html (dostęp: 6.01.2020). 
Liczba osób zaginionych utrzymuje się każdego roku na podobnym poziomie, natomiast w 2018 roku nieznacznie się zmniejszyła. Jej wzrost od 2012 do połowy 2018 roku może wynikać z obowiązywania w tym okresie Zarządzenia nr 124 Komendanta Głównego Policji ${ }^{2}$, zgodnie z którym definicję zaginięcia poszerzono o tzw. porwania rodzicielskie ${ }^{3}$. Obecnie obowiązujące Zarządzenie nr 48 Komendanta Głównego Policji powróciło do rozwiązań sprzed 2012 roku, rezygnując z kwalifikacji porwania rodzicielskiego jako zdarzenia polegającego na zaginięciu osoby (dziecka).

Z danych liczbowych zawartych w tabeli 1 wynika, że każdego roku w Polsce znika około dwudziestu tysięcy osób - oznacza to, iż każdego roku znika miasto wielkości Chełmna (woj. kujawsko-pomorskie) czy Gostynina (woj. mazowieckie). Zauważyć należy, że polska policja nie publikuje dokładnej informacji na temat liczby osób odnalezionych. Dane udostępnione przez komendę główną policji w Warszawie są zaskakujące: każdego roku odnajduje się ponad sto procent osób zaginionych (tabela 2). Procent osób odnalezionych wynoszący ponad sto może wynikać z faktu, iż jednostki organizacyjne policji na przestrzeni danego roku realizują również sprawy z poprzednich okresów sprawozdawczych. Oznacza to, że wśród osób odnalezionych mogą być osoby zaginione w bieżącym roku, jak również w latach ubiegłych.

2 Zarządzenie nr 124 Komendanta Głównego Policji z dnia 4 czerwca 2012 roku w sprawie prowadzenia przez Policję poszukiwania osoby zaginionej oraz postępowania w przypadku ujawnienia osoby o nieustalonej tożsamości lub znalezienia nieznanych zwłok oraz szczątków ludzkich, Dziennik Urzędowy Komendy Głównej Policji 2012, poz. 29.

${ }^{3}$ Zgodnie z § 2 Zarządzenia nr 48 Komendanta Głównego Policji z dnia 28 czerwca 2018 roku porwaniem rodzicielskim jest zdarzenie, w wyniku którego jedno z rodziców lub opiekunów prawnych posiadających władzę rodzicielską bez woli i wiedzy drugiego z nich pod pretekstem krótkotrwałego pobytu wywozi lub zatrzymuje osobę małoletnią na stałe, pozbawiając tym samym drugiego rodzica lub opiekuna prawnego posiadającego władzę rodzicielską możliwości utrzymywania kontaktu z małoletnim w przysługującym mu zgodnie z prawem zakresie. 
Tabela 2. Liczba odnalezionych osób zaginionych w ciągu roku

\begin{tabular}{|l|c|c|}
\hline Rok & Liczba osób & $\begin{array}{c}\text { \% osób } \\
\text { odnalezionych }\end{array}$ \\
\hline 2018 & 18127 & 105,32 \\
\hline 2017 & 19807 & 101,25 \\
\hline 2016 & 19683 & 101,22 \\
\hline 2015 & 20637 & 100,87 \\
\hline 2014 & 21094 & 101,19 \\
\hline 2013 & 19782 & 100,84 \\
\hline 2012 & 17890 & 99,56 \\
\hline 2011 & 15515 & 99,35 \\
\hline 2010 & 14150 & 98,31 \\
\hline 2009 & 14912 & 98,91 \\
\hline 2008 & 15700 & 98,86 \\
\hline 2007 & 15449 & 98,58 \\
\hline 2006 & 15162 & 98,81 \\
\hline 2005 & 13746 & 96,73 \\
\hline 2004 & 15070 & 99,41 \\
\hline
\end{tabular}

Źródło: dane otrzymane za pośrednictwem poczty elektronicznej, Komenda Główna Policji, Gabinet Informacji Publicznej, 6 listopada 2019 roku.

\section{Grupy poszukiwawczo-ratownicze w Polsce}

Nieocenionym wsparciem policji jako wiodącego podmiotu zaangażowanego w poszukiwanie zaginionych okazują się być grupy poszukiwawcze. Zaginięcie osoby może zagrażać jej zdrowiu, a nawet życiu, co rodzi po stronie organów państwowych obowiązek współpracy i koordynacji podmiotów zajmujących się szeroko rozumianym ratownictwem. Niejednokrotnie bowiem zdarza się, że policja nie dysponuje takimi zasobami ludzkimi czy specjalistycznym sprzętem, jak pozostałe podmioty poszukiwawcze. 


\section{PSP oraz OSP}

Współpraca policji z jednostkami straży pożarnej wynika z zawartego pomiędzy Komendantem Głównym Państwowej Straży Pożarnej a Komendantem Głównym Policji porozumienia z dnia 12 czerwca 2001 roku o współdziałaniu Państwowej Straży Pożarnej i Policji ${ }^{4}$. Zgodnie z dokumentem na wniosek policji do działań poszukiwawczych mogą być dysponowane Specjalistyczne Grupy Poszukiwawczo-Ratownicze Krajowego Systemu Ratowniczo-Gaśniczego (SGPR KSRG). Powyższy układ między formacjami jest źródłem analogicznych porozumień zawieranych przez komendy wojewódzkie i powiatowe, które są wyrazem woli współpracy. Współpraca straży pożarnej i policji polega przede wszystkim na organizacji wspólnych działań ratowniczych, szkoleń i innych przedsięwzięć mających na celu propagowanie działań prewencyjnych, ochronnych i ewakuacyjnych.

Jednostki działające przy ochotniczej straży pożarnej odgrywają w procesie poszukiwania zaginionej osoby bardzo dużą rolę. Ochotnicza straż pożarna jest organizacją społeczną i znajduje się w strukturze Związku Ochotniczych Straży Pożarnych. Obecnie (stan na dzień 31 grudnia 2018 roku) do KSRG włączonych jest 4439 jednostek OSP (około 25\% wszystkich jednostek). Dysponowanie SGPR zrzeszonych w KSRG odbywa się w oparciu o algorytmy postępowania (il. 1-4). Wniosek o zadysponowanie grupy poszukiwawczo-ratowniczej może być złożony w wypadku zakwalifikowania zdarzenia do pierwszego poziomu zaginięcia. Wnioskowanie o dyspozycję grupy poszukiwawczo-ratowniczej powinno być każdorazowo potwierdzone pisemnie i niezwłocznie przesłane do stanowiska kierowania. Algorytm A dotyczy działań w powiecie, na terenie którego działa SGPR zrzeszona w KSRG. Dysponowanie takiej grupy na wniosek policji powinno odbywać się tylko na poziomie powiatu właściwego ze względu na kompetencje działania danej grupy. W innych wypadkach dysponowanie grup poszukiwawczych winno odbywać się za pośrednictwem właściwego stanowiska kierowania państwowej straży pożarnej, a ich realizacja powinna nastąpić przez wojewódzkie stanowiska kierowania policji (algorytm B lub C). Zgodnie z algorytmem D czynność ta powinna być

4 Porozumienie z dnia 12 czerwca 2001 roku pomiędzy Komendantem Głównym Policji a Komendantem Głównym Państwowej Straży Pożarnej o współdziałaniu Państwowej Straży Pożarnej i Policji, Dziennik Urzędowy Komendy Głównej Policji 2001, nr 8, poz. 95. 
realizowana przez wojewódzkiego lub krajowego koordynatora Centrum Poszukiwań Osób Zaginionych (CPOZ) lub Wydział Poszukiwań i Identyfikacji Osób Biura Służby Kryminalnej Komendy Głównej Policji (z jednoczesnym powiadomieniem $\mathrm{CPOZ}$ ).

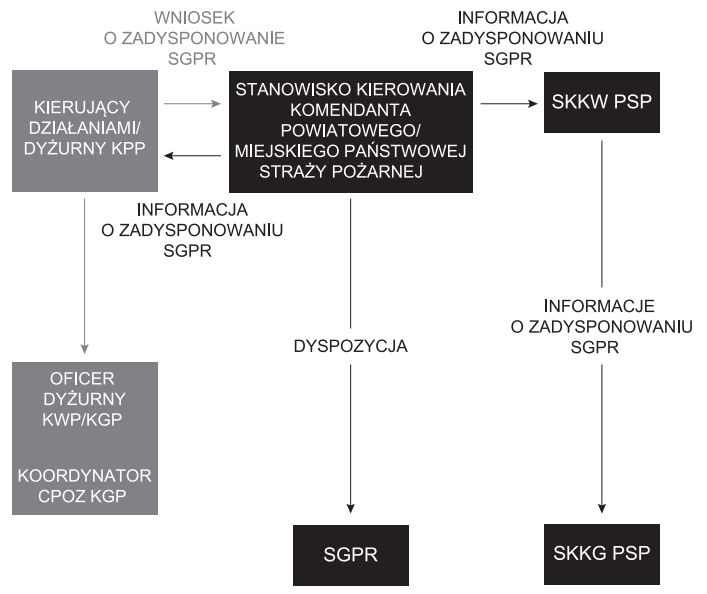

Il. 1. Algorytm A - algorytm postępowania podczas działań w powiecie, na terenie którego działa Specjalistyczna Grupa Poszukiwawczo-Ratownicza Krajowego Systemu Ratowniczo-Gaśniczego

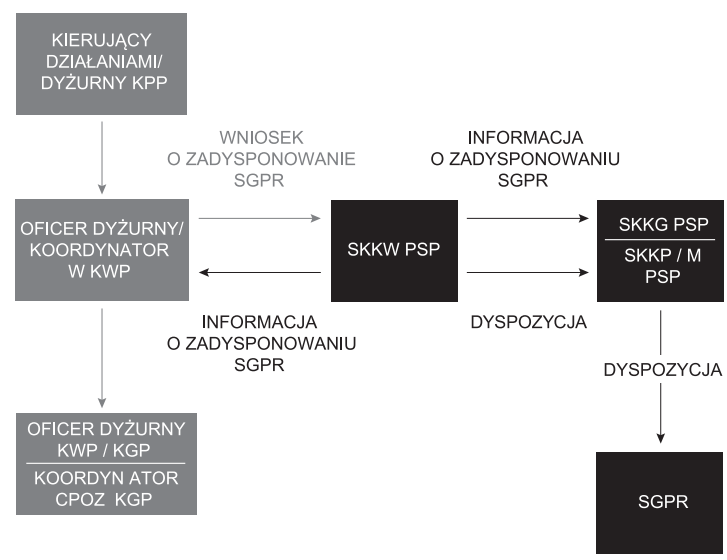

I1. 2. Algorytm B - algorytm postępowania podczas działań w powiecie, na terenie którego nie działa Specjalistyczna Grupa Poszukiwawczo-Ratownicza Krajowego Systemu Ratowniczo-Gaśniczego, ale działa na terenie województwa 


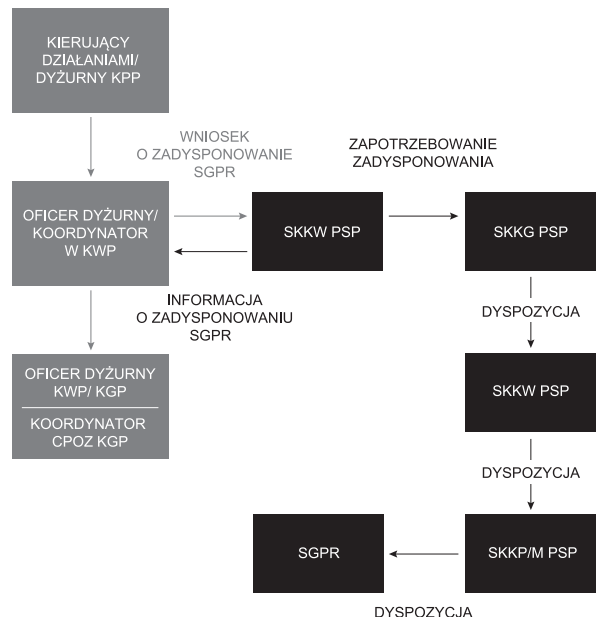

Il. 3. Algorytm $\mathrm{C}$ - algorytm postępowania podczas działań w powiecie, na terenie którego nie działa Specjalistyczna Grupa Poszukiwawczo-Ratownicza Krajowego

Systemu Ratowniczo-Gaśniczego i nie działa na terenie województwa

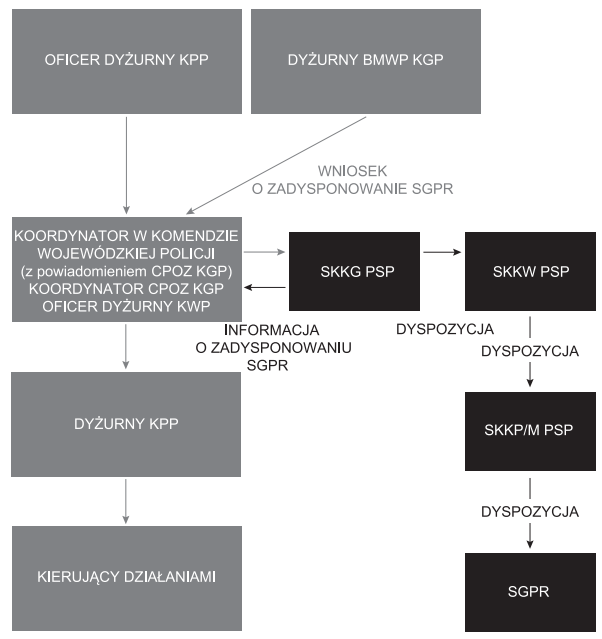

I1. 4. Algorytm D - algorytm postępowania podczas działań w powiecie, na terenie którego nie działa Specjalistyczna Grupa Poszukiwawczo-Ratownicza Krajowego Systemu Ratowniczo-Gaśniczego i nie działa na terenie województwa

Źródło: Procedura dysponowania Specjalistycznych Grup Poszukiwawczo-Ratowniczych Krajowego Systemu Ratowniczo-Gaśniczego do działań poszukiwawczych prowadzonych w terenie, http://www. zaginieni.pl/jak-pomagamy/wsparcie-dla-rodzin/pobierz-broszury-informacyjne/ (dostęp: 28.01.2020).

Nowa Kodyfikacja Prawa Karnego 56, 2020

(C) for this edition by CNS 
Opracowanie algorytmów regulujących zasady dysponowania SGPR znacznie ułatwiło współpracę podmiotów i zwiększyło efektywność akcji poszukiwawczych. Organizacją oraz planowaniem działań poszukiwawczych zajmuje się policja, która jako podmiot wiodący odpowiada za akcję poszukiwawczą.

\section{WOPR}

Współpraca policji z WOPR realizowana jest poprzez Porozumienie z dnia 20 czerwca 2007 roku pomiędzy Komendantem Głównym Policji a Prezesem Zarządu Głównego Wodnego Ochotniczego Pogotowia Ratunkowego w sprawie współdziałania w zakresie bezpieczeństwa i porządku publicznego na wodach i terenach przywodnych ${ }^{5}$. Opiera się przede wszystkim na współdziałaniu w celu poprawy bezpieczeństwa na terenach wodnych i przywodnych. Realizacja postanowień porozumień zawieranych między tymi podmiotami odbywa się m.in. poprzez organizowanie działań ratowniczych wobec osób, które uległy wypadkowi albo ich życie lub zdrowie jest narażone na niebezpieczeństwo, ale także poprzez podejmowanie działań o charakterze prewencyjnym i szkoleniowym.

\section{GOPR oraz TOPR}

Działalność obu tych podmiotów zajmujących się ratownictwem w górach wynika z ustawy z dnia 18 sierpnia 2011 roku o bezpieczeństwie i ratownictwie $w$ górach i na zorganizowanych terenach narciarskich $^{6}$. Wyspecjalizowani ratownicy, a także wypracowane przez nich metody poszukiwań zaginionych na terenach górskich stanowią nieocenioną pomoc w działaniach poszukiwawczych. Specyfika poszukiwań w górach wymaga specjalistycznego sprzętu i wielu nowych technologii.

5 Porozumienie pomiędzy Komendantem Głównym Policji a Prezesem Zarządu Głównego Wodnego Ochotniczego Pogotowia Ratunkowego, Dziennik Urzędowy Komendy Głównej Policji 2007, nr 13, poz. 106.

${ }^{6}$ Ustawa z dnia 18 sierpnia 2011 roku o bezpieczeństwie i ratownictwie w górach i na zorganizowanych terenach narciarskich, Dz.U. 2019 poz. 1084. 
Obie grupy współpracują z policją na podstawie stosownych porozumień, w których określono formy współpracy, m.in. poprzez organizowanie wspólnych szkoleń czy udostępnienie specjalistycznego sprzętu.

\section{Stowarzyszenia cywilne}

Obecnie wśród podmiotów poszukiwawczych znaczącą rolę odgrywają stowarzyszenia cywilne (np. Stowarzyszenie SiR „Szukamy i Ratujemy" — zob. il. 3). Przyjęcie członka do takiej grupy zależy najczęściej od spełnienia wymogów regulaminowych (np. chęć niesienia pomocy, zainteresowanie tematem poszukiwań, posiadanie specjalistycznych umiejętności czy poparcie kandydatury przez co najmniej dwóch członków stowarzyszenia). Wskazać należy, że często są to osoby wyszkolone, posiadające odpowiedni sprzęt i doświadczenie (ratownicy medyczni, ratownicy wodni, strażacy, pielęgniarze itd.), ale nierzadko do takich stowarzyszeń przystępują także osoby nieposiadające nawet minimalnej wiedzy na temat specyfiki poszukiwań (co może budzić kontrowersje). Brak wiedzy oraz doświadczenia $\mathrm{w}$ temacie specyfiki działań poszukiwawczych może być źródłem problemów i niekorzystnie wpływać na przebieg akcji poszukiwawczo-ratowniczej (np. poprzez zatarcie istotnych śladów przez niedoświadczonego członka grupy).

Stowarzyszenia cywilne zajmujące się poszukiwaniem osób zaginionych działają zazwyczaj na podstawie wewnętrznych statutów. Charakter takiej działalności pozwala na niezależność podmiotu, jednakże z uwagi na to, że grupy te nie są objęte KSRG, dysponowanie ich do działań poszukiwawczych napotyka wiele problemów. Zasadniczo mogą być one dysponowane poprzez bezpośredni kontakt z dowódcą grupy. Zazwyczaj przybywają jednak na miejsce zdarzenia samowolnie, a o zdarzeniu dowiadują się przede wszystkim z mediów lub są informowane przez członków innych grup poszukiwawczych.

Celem zweryfikowania wykorzystania potencjału grup cywilnych podczas działań poszukiwawczych autorka tekstu zwróciła się pisemnie do 69 grup poszukiwawczych działających na terenie całej Polski z prośbą o udzielenie informacji na temat współpracy tych podmiotów z policją podczas poszukiwań zaginionych (gromadzenia stosownych danych statystycznych) oraz na temat posiadanego sprzętu. Badaniem objęto grupy 
poszukiwawczo-ratownicze działające w strukturach PSP, OSP, PCK, GOPR, WOPR, TOPR oraz podmioty cywilne. Uzyskano odpowiedź od około 20\% uczestników badania. Praktycznie wszystkie grupy przyznały, że nie gromadzą informacji na temat udziału w akcjach poszukiwawczych. Fakt ten może negatywnie wpływać na dysponowanie takich grup przez policję, obecnie trudno bowiem stwierdzić, w ilu akcjach poszukiwawczych prowadzonych przez policję wykorzystuje się potencjał innych podmiotów i jakie jest zapotrzebowanie na pomoc takich grup. Skrupulatne prowadzenie statystyk mogłoby wymusić na aparacie państwowym konieczność uregulowania współpracy między służbami państwowymi (policja, straż pożarna) a innymi organizacjami. Wskazywano także na bogate wyposażenie sprzętowe, ale dotychczasowy brak jego wykorzystania w akcjach poszukiwawczych, brak środków finansowych na stworzenie grupy czy specjalistyczne szkolenia, a nawet likwidację niedawno powstałych grup z powodu braku środków finansowych.

Zrealizowany w 2015 roku przez Fundację ITAKA projekt pt. Monitoring działań Policji w poszukiwaniach zaginionych na otwartym tere$n i e^{7}$ wykazał, że brak uregulowania kwestii współpracy policji z grupami poszukiwawczo-ratowniczymi stanowi ogromny problem. Celem projektu był monitoring działań policji w zakresie wykorzystania innych podmiotów poszukiwawczych podczas poszukiwań osób zaginionych oraz uregulowanie procedur dysponowania tych grup przez policję. Analiza problemu opierała się głównie na wywiadach oraz ankietach, które dostosowano do grupy badawczej. Funkcjonariusze jednostek policji oraz członkowie grup poszukiwawczych wskazali na najczęściej występujące problemy w sferze współpracy. 97\% badanych funkcjonariuszy policji podkreśliło konieczność współpracy z innymi podmiotami w poszukiwaniach osób zaginionych. Wśród problemów najczęściej wskazywanych przez podmioty pozapolicyjne wymienić można:

— brak dysponowania grupy do działań poszukiwawczych (m.in. ze względu na brak wiedzy o działalności grupy),

- brak uregulowanych zasad współpracy między policją i grupą,

— brak zwrotu kosztów wyjazdu grupy poza gminę,

7 Raport z projektu „Monitoring działań Policji $w$ poszukiwaniach zaginionych na otwartym terenie”, Warszawa 2015, http:/www.itaka.org.pl/wp-content/uploads/2015/01/raport_2015_Fundacja-ITAKA-net.pdf (dostęp: 30.01.2020). 
— brak środków finansowych na wyposażenie grupy w specjalistycznych sprzęt ${ }^{8}$.

Ankietowani funkcjonariusze policji zwrócili natomiast uwagę na poniższe przeszkody wpływające na częstotliwość dysponowania do działań innych podmiotów:

— odpowiedzialność za prowadzoną akcję,

- znaczna odległość grupy od prowadzonych poszukiwań (co powoduje wydłużenie czasu dojazdu na miejsce poszukiwań),

—ilość dokumentacji związanej z zadysponowaniem grupy (pisemny wniosek, raporty itd.),

- słaba koordynacja wspólnych działań,

- udział osób cywilnych w poszukiwaniach (co skutkuje dodatkowym obowiązkiem czuwania nad bezpieczeństwem tej osoby przez funkcjonariuszy policji),

— obawa o finansowanie kosztów akcji poszukiwawczej (np. dojazdu na akcję),

— obawa o brak wiedzy i doświadczenia członków organizacji na temat specyfiki akcji ${ }^{9}$.

\section{Podsumowanie}

Z powodu newralgicznego charakteru zjawiska zaginięcia oraz w związku z obowiązkiem chronienia zdrowia i życia człowieka konieczne jest uregulowanie współpracy oraz określenie zasad i procedur dysponowania do akcji poszukiwawczych grup poszukiwawczo-ratowniczych (w szczególności grup nieuwzględnionych w KSRG). Ogromnie ważną kwestią jest także opracowanie procedur wzajemnego informowania o zapotrzebowaniu włączenia grupy do poszukiwań terenowych.

Ryzyko związane $\mathrm{z}$ udziałem $\mathrm{w}$ akcjach poszukiwawczych osób nieposiadających wiedzy i doświadczenia w tego typu działaniach wskazuje na potrzebę stworzenia kryteriów określających, jaka organizacja może nazywać się grupą poszukiwawczą (np. określenie, z jakich członków może składać się grupa, konieczność uzyskania stosownych szkoleń/certyfikatów).
8 Ibidem, s. 24.
9 Ibidem, s. 19-20. 
Wskazać także należy, że współpraca winna obejmować zwiększenie liczby specjalistycznych szkoleń zgłębiających wiedzę teoretyczną oraz praktyczną (m.in. poprzez analizę podejmowanych działań), a także wspólne manewry poszukiwawcze na różnego typu obszarach (tereny zalesione, górzyste, wodne itd.). Praktyczne wykorzystanie wiedzy i doświadczenia mogłoby znacząco wpłynąć na system poszukiwania zaginionych i zwiększyć efektywność działań.

\section{Bibliografia}

Procedura dysponowania Specjalistycznych Grup Poszukiwawczo-Ratowniczych Krajowego Systemu Ratowniczo-Gaśniczego do działań poszukiwawczych prowadzonych $w$ terenie, http://www.zaginieni.pl/jak-pomagamy/wsparcie-dla-rodzin/ pobierz-broszury-informacyjne/ (dostęp: 28.01.2020).

Raport z projektu ,Monitoring działań Policji w poszukiwaniach zaginionych na otwartym terenie", Warszawa, 2015, http://www.itaka.org.pl/wp-content/uploads/2015/01/ raport2015_Fundacja-ITAKA-net.pdf (dostęp: 30.01.2020).

\section{Akty prawne}

Porozumienie pomiędzy Komendantem Głównym Policji a Prezesem Zarządu Głównego Wodnego Ochotniczego Pogotowia Ratunkowego, Dziennik Urzędowy Komendy Głównej Policji 2007, nr 13, poz. 106.

Porozumienie z dnia 12 czerwca 2001 roku pomiędzy Komendantem Głównym Policji a Komendantem Głównym Państwowej Straży Pożarnej o współdziałaniu Państwowej Straży Pożarnej i Policji, Dziennik Urzędowy Komendy Głównej Policji 2001, nr 8, poz. 95 .

Ustawa z dnia 18 sierpnia 2011 roku o bezpieczeństwie i ratownictwie w górach i na zorganizowanych terenach narciarskich, Dz.U. 2019 poz. 1084.

Zarządzenie nr 124 Komendanta Głównego Policji z dnia 4 czerwca 2012 roku w sprawie prowadzenia przez Policję poszukiwania osoby zaginionej oraz postępowania w przypadku ujawnienia osoby o nieustalonej tożsamości lub znalezienia nieznanych zwłok oraz szczątków ludzkich, Dziennik Urzędowy Komendy Głównej Policji 2012, poz. 29.

Zarządzenie nr 48 Komendanta Głównego Policji z dnia 28 czerwca 2018 roku w sprawie prowadzenia przez Policję poszukiwania osoby zaginionej oraz postępowania w przypadku ujawnienia osoby o nieustalonej tożsamości lub znalezienia nieznanych zwłok oraz szczątków ludzkich, Dziennik Urzędowy Komendy Głównej Policji 2018, poz. 77. 


\section{Źródła interetowe}

Serwis internetowy www.zaginieni.pl: http://www.zaginieni.pl/jak-pomagamy/wsparcie-dla-rodzin/pobierz-broszury-informacyjne/ (dostęp: 30.01.2020).

Strona internetowa policji: http://statystyka.policja.pl/st/wybrane-statystyki/zaginieni /50885,Zaginieni.html (dostęp: 30.01.2020).

\section{The reality of functioning of search and rescue groups in Poland}

Summary

The disappearance of a person is an event that demands coordination of the entities involved in the search for missing persons. Cooperation of governmental search and rescue services with other entities specializing in search operations is of great importance in the system of locating missing persons, as it increases the chances of saving the life of a lost person.

Keywords: person disappearance, search, cooperation. 